\title{
Studies for culturing and cultivation of Lentinus cladopus Lév.
}

\author{
Atri NS and Lata
}

Department of Botany, Punjabi University, Patiala, 147 002, Punjab, India

E-mail:-narinderatri04@yahoo.com,lg85.lataguleria@rediff.com

Atri NS and Lata 2013 - Studies for culturing and cultivation of Lentinus cladopus Lév. Mycosphere 4(4), 675-682, Doi 10.5943/mycosphere/4/4/3

\begin{abstract}
In this paper the results of the vegetative growth of Lentinus cladopus Lév. on twelve solid media and eleven liquid media and reproductive growth on lignocellulosic substrates have been presented. Malt Extract Agar medium (MEA) supported the best mycelial growth from amongst the solid media evaluated while the vegetative growth on Malt Broth (MB) was maximum amongst the liquid media screened for the purpose. L. cladopus when grown on different lignocellulosic substrates including wheat straw, paddy straw and their 1:1 mixture gave $33.35 \%$ biological efficiency on 1:1 mixture of wheat straw and paddy straw, which was best as compared to $31.66 \%$ biological efficiency obtained on wheat straw and $12.76 \%$ biological efficiency obtained on paddy straw.
\end{abstract}

Keywords - Lentinus cladopus - lignocellulosic substrates - liquid media - solid media

\section{Introduction}

Mushrooms are amongst the most popular food items accepted the world over. The increased consumer demand over the years has resulted in production of mushrooms in large proportions (Thakur 1995) through cultivation which is a highly efficient method for recycling the agricultural residues so as to produce nutritious food (Chang et al. 1998). Many species of genus Lentinus Fr. including L. cladopus Lév. are reported to be edible which can be cultivated on pasteurized as well as unpasteurized substrates (Morais et al. 2000). Taxonomically L. cladopus is quite close to L. squarrosulus Mont. in having a similar morphology and hyphal construction but differs from it in having thin pileus, lacking squamules and presence of broader spores. Basidiocarps of this mushroom appear in caespitose clusters. It is characterized by membranous whitish smooth convex depressed to subinfundibuliform pileus and cylindrical concolorous stipe (Peglar 1977). Some preliminary investigations on culturing of this mushroom have been done by Natarajan \& Raaman (1981). They are reported to have attempted its cultivation on paddy straw mixed with sawdust (Purkayastha \& Chandra 1985). All such species are used by the people because of the presence of significant amount of proteins, lipids, fats, minerals, vitamins in them from dietary point of view (Chang \& Miles 2004). This paper presents study on L. cladopus which was collected from the wild, brought into pure culture on Potato Dextrose Agar medium and cultured on different solid as well as liquid media for selecting the best medium supporting vegetative growth. Later on it was cultivated on wheat straw, paddy straw and their 1:1 mixture and biological efficiency was also determined. 


\section{Materials and Methods}

\section{The Material}

The mushroom fruit body of L. cladopus was collected from Palampur (Himachal Pradesh) in North-West India from the stem of Albizia chinensis (Osbeck) Merrill. It was taxonomically investigated and identified (Pegler 1983). Molecular sequence has been deposited in NCBI Gene Bank (accession number JQ868754). The specimen (PUN-3948) has been deposited in the Herbarium of Botany Department, Punjabi University, Patiala (Punjab), India. The pure culture was raised on the Potato Dextrose Agar medium by tissue culture method (Yadav 2005). The culture has been deposited at Microbial Type Culture Collection and Gene Bank, Institute of Microbial Technology (IMTECH) Chandigarh, India under MTCC No. 10948.

\section{Media Used}

Both solid as well as liquid media were evaluated for the vegetative growth of $L$. cladopus. The composition of each medium used was based on Tuite (1969). The twelve solid media, used for evaluation are Malt Extract Agar (MEA), Potato Dextrose Agar (PDA), Pea Extract Agar (PEA), Milk Powder Agar (MPA), Potato Malt Agar (PMA), Yeast Extract Agar (YEA), Yeast Potato Dextrose Agar (YPDA), Gram Grain Extract Agar (GGEA), Dimmick Medium (DM), Maize Grain Extract Agar (MGEA), Wheat Grain Extract Agar (WGEA) Czapek Solution Agar (CSA) and eleven liquid media, namely Malt Broth (MB), Potato Dextrose Broth (PDB), Czapek Solution (CS), Glucose Asparagine Medium (GAM), Glucose Peptone Medium (GPM), Richard Solution (RS), Dimmick Medium (DM), Peptone Water (PW), Maltose Peptone Medium (MPM), Bilai Medium (BM) and Koser Citrate Medium (KCM) were used during experimentation for making comparative observation on vegetative growth of $L$. cladopus.

To measure the growth rate of mycelium in various solid media, the diameter of mycelial colonies was measured in $\mathrm{cm}$ scale and the average growth rate of mycelium was calculated. The mycelial density was assessed visually and expressed as described by Kadiri (1998) as follows:-

+ Very scanty, 2+ Scanty, 3+ Moderate, 4+ Abundant, 5+ Very Abundant.

So as to measure the mycelial growth rate in various liquid media, the mycelial mat from each flask was harvested, washed and dried at $65^{\circ} \mathrm{C}$ for 24 hours. The dry weight of mycelium was recorded for two subsequent days and an average of the two was taken as the actual weight.

\section{Spawn Preparation}

For spawn preparation, healthy wheat grains were taken and grain spawn was prepared using the standard methodology (FAO 1990). The grains were fully colonized after 10-15 days of inoculation which became ready for use after 17-20 days of incubation.

\section{Substrates and Substrate Preparation for Cultivation}

Wheat straw, paddy straw and mixture of two (1:1) were used in the present study for cultivation. The substrates were prepared using standard methodology based on Upadhyay (1990). The colonized bags were incubated for fruiting after complete colonization. The polythene bags were removed on emergence of primordia which took 7-15 days after spawning. Later on each colonized substrate cylinder was immersed in the ice cold water for about 5 minutes for giving chilling treatment. These colonized substrate cylinders were then transferred to cropping room and kept on open racks. During cropping, water was sprayed after every two hours depending upon the requirement to keep the substrate moist. The relative humidity in the cropping room was maintained at $90-95 \%$ with the help of humidifier and temperature was maintained between $20-22^{\circ} \mathrm{C}$ during fruiting. The fruit bodies were harvested and fresh weight and dry weight of mushrooms harvested in each flush was recorded.

\section{Biological Efficiency}

Biological efficiency of the mushroom with individual substrate and mixture was 
Table 1 Mean colony diameter $(\mathrm{cm})$ in different solid media \pm standard deviation (SD) and mycelial characteristics.

\begin{tabular}{|c|c|c|}
\hline Name of Medium & $\begin{array}{c}\text { Mean Colony } \\
\text { Diameter }(\mathrm{cm}) \pm \\
\text { Standard } \\
\text { Deviation }\end{array}$ & Mycelium Characteristics \& Density \\
\hline $\begin{array}{l}\text { Malt Extract Agar } \\
\text { (MEA) }\end{array}$ & $4.88 \pm 0.13$ & $\begin{array}{l}\text { Dense thick mycelial growth in concentric rings with white } \\
\text { appearance }(5+)\end{array}$ \\
\hline $\begin{array}{l}\text { Potato Dextrose Agar } \\
\text { (PDA) }\end{array}$ & $4.80 \pm 0.18$ & $\begin{array}{l}\text { Uniform dense thick mycelial mat with concentric rings and } \\
\text { white appearance }(4+)\end{array}$ \\
\hline Pea Extract Agar (PEA) & $4.58 \pm 0.24$ & Uniform thin mycelial mat, filaments off-white in appearance $(3+)$ \\
\hline $\begin{array}{l}\text { Milk Powder Agar } \\
\text { (MPA) }\end{array}$ & $4.41 \pm 0.14$ & $\begin{array}{l}\text { Extremely thin filamentous mycelial growth whitish in } \\
\text { appearance }(3+)\end{array}$ \\
\hline Potato Malt Agar (PMA) & $4.35 \pm 0.18$ & Wrinkled, thin uniform mycelial growth, whitish in appearance $(3+)$ \\
\hline $\begin{array}{l}\text { Yeast Extract Agar } \\
\text { (YEA) }\end{array}$ & $4.30 \pm 0.23$ & $\begin{array}{l}\text { Thin uniform mycelial growth in concentric rings with white } \\
\text { appearance }(3+)\end{array}$ \\
\hline Yeast Potato Dextrose & $4.26 \pm 0.17$ & Thick mycelial growth, mat less thicker than that of Malt Extract \\
\hline Agar (YPDA) & & Agar and Potato Dextrose Agar, white in appearance (3+) \\
\hline $\begin{array}{l}\text { Gram Grain Extract } \\
\text { Agar (GGEA) }\end{array}$ & $4.24 \pm 0.12$ & $\begin{array}{l}\text { Thin mat of mycelium, growth in concentric rings with wrinkled } \\
\text { margin, off-white in appearance }(2+)\end{array}$ \\
\hline Dimmick Medium (DM) & $4.21 \pm 0.22$ & $\begin{array}{l}\text { Very thin, poorly developed, loosely arranged transparent } \\
\text { mycelial filaments off-white in colour }(+)\end{array}$ \\
\hline $\begin{array}{l}\text { Maize Grain Extract } \\
\text { Agar (MGEA) }\end{array}$ & $4.20 \pm 0.22$ & Uniform thin mycelial mat with white appearance $(+)$ \\
\hline $\begin{array}{l}\text { Wheat Grain Extract } \\
\text { Agar (WGEA) }\end{array}$ & $4.10 \pm 0.46$ & $\begin{array}{l}\text { Thin mycelial growth in concentric rings, light brown coloured } \\
\text { patches appear in due course }(+)\end{array}$ \\
\hline Czapek Dox Agar (CDA) & $4.00 \pm 0.48$ & $\begin{array}{l}\text { Extremely thin poor mycelial growth with loosely scattered } \\
\text { transparent mycelial filaments, whitish in appearance }(+)\end{array}$ \\
\hline
\end{tabular}

calculated on fresh weight basis as per the formula:-

Biological Efficiency $=\frac{\text { Fresh weight of mushroom }}{\text { Dry weight of mushroom }} \times 100$

\section{Results}

During evaluation of media, out of the twelve different solid media used for evaluation of vegetative growth, significantly higher vegetative growth was recorded in Malt Extract Agar (4.88 $\mathrm{cm})$ followed by Potato Dextrose Agar $(4.80 \mathrm{~cm})$. On an average daily basis the mycelium was found growing at the rate of $0.94 \mathrm{~cm}$ in diameter in Malt Extract Agar and mycelium formed a thick dense white mat with concentric rings with maximum mycelial density (5+). Least mycelial growth was recorded in Czapek Dox Agar $(4.00 \mathrm{~cm})$ with extremely poor mycelial density (+) in comparison to other media. The mean colony diameter of the fungus with \pm standard deviation (SD) and mycelium characteristics in different solid media are presented in table 1.

Out of the eleven different liquid media selected for evaluation of vegetative growth Malt Broth (MB) gave maximum vegetative growth $(8.63 \mathrm{mg} / \mathrm{ml})$ followed by Potato Dextrose Broth $(7.00 \mathrm{mg} / \mathrm{ml})$. On the other hand, minimum vegetative growth was obtained in Koser Citrate Medium $(0.50 \mathrm{mg} / \mathrm{ml})$. The vegetative growth obtained in eleven different liquid media with \pm standard deviation (SD) has been presented in table 2 .

As per t-values obtained the difference of vegetative growth in Malt Extract Agar (solid medium) and Malt Broth (liquid medium) was significantly higher than in all other media evaluated. Matrix table showing t-values obtained for mycelial growth on solid media and liquid media are given in table 3 and 4, respectively.

From amongst the lignocellulosic substrates used for cultivation wheat straw bags were fully colonized after 7-8 days of inoculation. Bags of mixture substrate took 9-11 days while paddy straw bags took 13-15 days for complete colonization. Small protuberances appeared in each 
Table 2 Mean dry weight in different liquid media \pm standard deviation (SD).

\begin{tabular}{lc}
\hline \multicolumn{1}{c}{ Name of Medium } & Mean Dry Weight $(\mathbf{m g} / \mathbf{m l}) \pm$ Standard Deviation \\
\hline Malt Broth (MB) & $8.63 \pm 1.89$ \\
Potato Dextrose Broth (PDB) & $7.00 \pm 0.71$ \\
Czapek Dox Solution (CDS) & $6.50 \pm 3.55$ \\
Glucose Asparagine Medium (GAM) & $5.70 \pm 0.57$ \\
Glucose Peptone Medium (GPM) & $5.50 \pm 1.73$ \\
Richard Solution (RS) & $2.50 \pm 0.79$ \\
Dimmick Medium (DM) & $2.25 \pm 0.35$ \\
Peptone Water (PW) & $1.38 \pm 0.75$ \\
Maltose Peptone Medium (MPM) & $1.25 \pm 0.50$ \\
Bilai Medium (BM) & $0.83 \pm 0.29$ \\
Koser Citrate Medium (KCM) & $0.50 \pm 0.00$ \\
\hline
\end{tabular}

in wheat straw substrate and $12.76 \%$ biological efficiency in paddy straw. The observations are summarized in the table 5 .

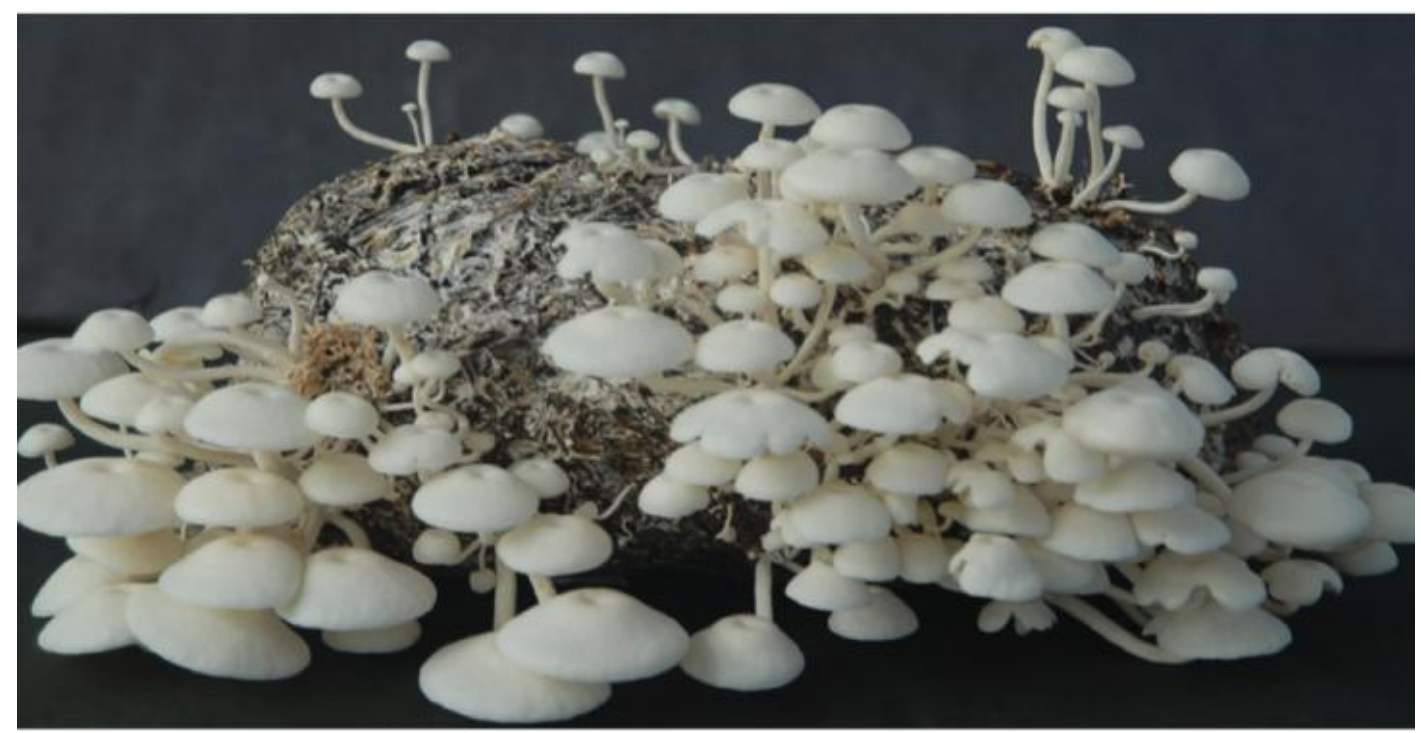

Fig. 1 - Fruiting bodies of L. cladopus on 1:1 mixture of Wheat straw and Paddy straw.

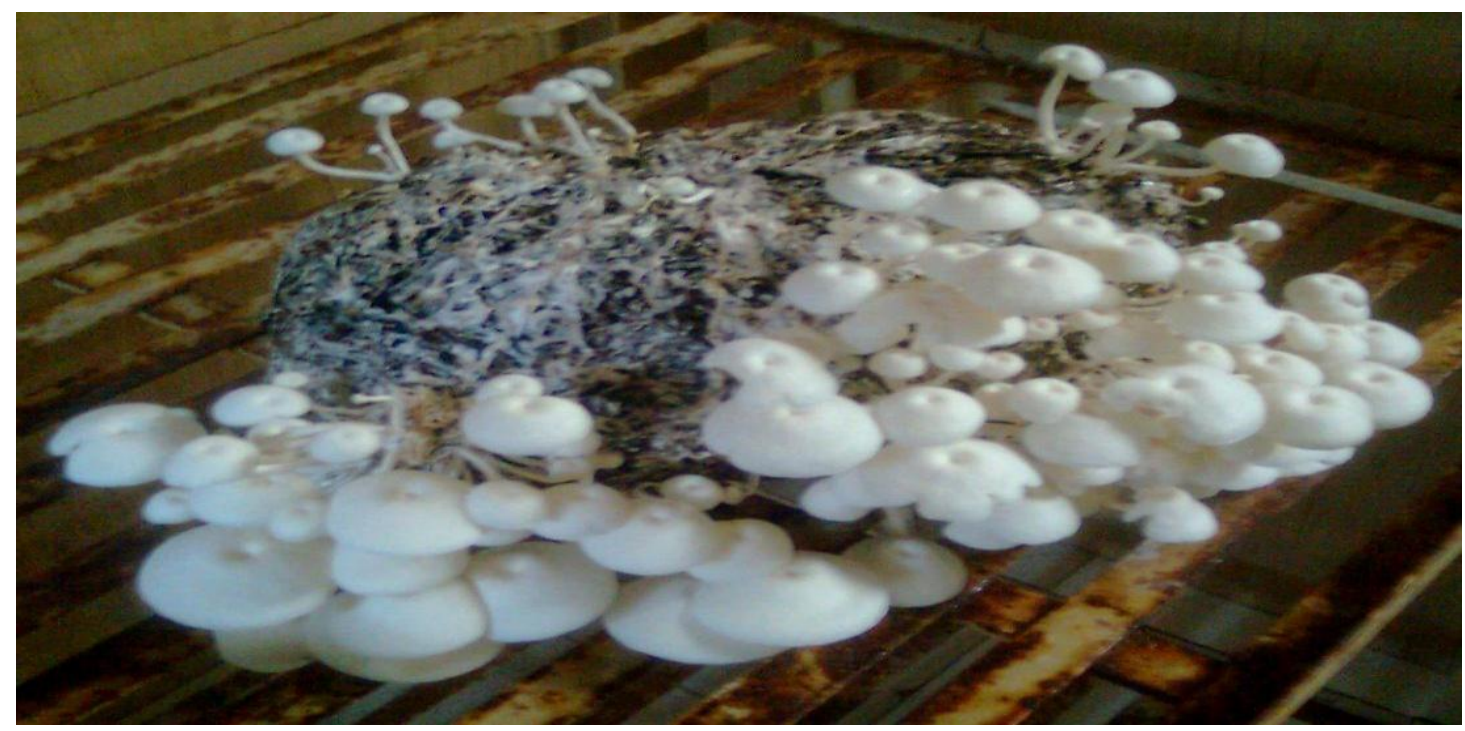

Fig. 2 - Fruiting bodies of L. cladopus on Wheat straw. 
Table 3 Matrix table showing t-values of different solid media used for mycelial growth of L. cladopus.

\begin{tabular}{|c|c|c|c|c|c|c|c|c|c|c|c|c|c|}
\hline Name of Medium & Mean Diameter $(\mathrm{cm})$ & $\begin{array}{c}\text { MEA } \\
4.88\end{array}$ & $\begin{array}{c}\text { PDA } \\
4.80\end{array}$ & $\begin{array}{l}\text { PEA } \\
4.58\end{array}$ & $\begin{array}{c}\text { MPA } \\
4.41\end{array}$ & $\begin{array}{c}\text { PMA } \\
4.35\end{array}$ & $\begin{array}{l}\text { YEA } \\
4.30\end{array}$ & $\begin{array}{c}\text { YPDA } \\
4.26\end{array}$ & $\begin{array}{c}\text { GGEA } \\
4.24\end{array}$ & $\begin{array}{l}\mathrm{DM} \\
4.21\end{array}$ & $\begin{array}{c}\text { MGEA } \\
4.20\end{array}$ & $\begin{array}{c}\text { WGEA } \\
4.10\end{array}$ & $\begin{array}{l}\text { CDA } \\
4.00\end{array}$ \\
\hline Malt Extract Agar (MEA) & 4.88 & -- & 0.721 & $2.206^{*}$ & $4.896 * *$ & $4.775^{* *}$ & $3.919 * *$ & $5.254 * *$ & $7.529 * *$ & $4.718 * *$ & $5.313 * *$ & $3.264 * *$ & $3.534 * *$ \\
\hline Potato Dextrose Agar (PDA) & 4.80 & & -- & 1.467 & $3.421 * *$ & $3.543 * *$ & $3.125 * *$ & $4.060 * *$ & $5.185 * *$ & $3.782 * *$ & $4.225^{* *}$ & $2.834 * *$ & $3.125 * *$ \\
\hline Pea Extract Agar (PEA) & 4.58 & & & -- & 1.223 & 1.533 & 1.564 & $2.065^{*}$ & $2.537^{*}$ & $2.114^{*}$ & $2.331^{*}$ & $1.853^{*}$ & $2.164^{*}$ \\
\hline Milk Powder Agar (MPA) & 4.41 & & & & -- & 0.526 & 0.733 & 1.250 & $1.847 *$ & 1.379 & 1.615 & 1.292 & 1.640 \\
\hline Potato Malt Agar (PMA) & 4.35 & & & & & -- & 0.313 & 0.677 & 1.019 & 0.897 & 1.056 & 1.012 & 1.367 \\
\hline Yeast Extract Agar (YEA) & 4.30 & & & & & & -- & 0.242 & 0.411 & 0.889 & 0.581 & 0.752 & 1.095 \\
\hline Yeast Potato Dextrose Agar (YPDA) & 4.26 & & & & & & & -- & 0.174 & 0.311 & 0.408 & 0.640 & 1.004 \\
\hline Gram Grain Extract Agar (GGEA) & 4.24 & & & & & & & & -- & 0.214 & 0.321 & 0.588 & 0.972 \\
\hline Dimmick Medium (DM) & 4.21 & & & & & & & & & -- & 0.595 & 0.418 & 0.775 \\
\hline Maize Grain Extract Agar (MGEA) & 4.20 & & & & & & & & & & -- & 0.392 & 0.758 \\
\hline Wheat Grain Extract Agar (WGEA) & 4.10 & & & & & & & & & & & -- & 0.301 \\
\hline Czapek Dox Agar (CDA) & 4.00 & & & & & & & & & & & & -- \\
\hline
\end{tabular}

Table 4 Matrix table showing t-values of different liquid media used for mycelial growth of L. cladopus.

\begin{tabular}{|c|c|c|c|c|c|c|c|c|c|c|c|c|}
\hline Name of Medium & & MB & PDB & $\mathrm{CDS}$ & GAM & GPM & $\mathrm{RS}$ & $\mathrm{DM}$ & PW & MPM & $\mathrm{BM}$ & KCM \\
\hline & Mean Dry Wt. (mg/ml) & 8.63 & 7.00 & 6.50 & 5.70 & 5.50 & 2.50 & 2.25 & 1.38 & 1.25 & 0.83 & 0.50 \\
\hline Malt Broth ( MB) & 8.63 & -- & 1.523 & 1.153 & $2.996 * *$ & $2.563^{*}$ & $6.081 * *$ & $6.537 * *$ & $7.136 * *$ & $7.554 * *$ & $8.133 * *$ & $8.612 * *$ \\
\hline Potato Dextrose Broth (PDB) & 7.00 & & -- & 0.300 & $2.309^{*}$ & 1.626 & $7.341 * *$ & $8.497 * *$ & $8.978 * *$ & $10.268 * *$ & $11.663 * *$ & $12.974 * *$ \\
\hline Czapek Dox Solution (CDS) & 6.50 & & & -- & 0.498 & 0.566 & $2.460 *$ & $2.646^{*}$ & $3.139 * *$ & $3.267 * *$ & $3.553 * *$ & $3.781 * *$ \\
\hline Glucose Aspargine Medium (GAM) & 5.70 & & & & -- & 0.246 & $7.356^{* *}$ & $9.746^{* *}$ & $9.558 * *$ & $12.606^{* *}$ & $16.073^{* *}$ & $20.635 * *$ \\
\hline Glucose Peptone Medium (GPM) & 5.50 & & & & & -- & $3.529 * *$ & $4.007 * *$ & $4.796 * *$ & $5.234 * *$ & $5.904 * *$ & $6.468 * *$ \\
\hline Richard Solution (RS) & 2.50 & & & & & & -- & 0.581 & $2.183^{*}$ & $2.900 * *$ & $4.293 * *$ & $5.682 * *$ \\
\hline Dimmick Medium (DM) & 2.25 & & & & & & & -- & $1.942 *$ & $2.849 * *$ & $4.765 * *$ & $7.114 * *$ \\
\hline Peptone Water (PW) & 1.38 & & & & & & & & -- & 0.289 & 1.345 & $2.353^{*}$ \\
\hline Maltose Peptone Medium (MPM) & 1.25 & & & & & & & & & -- & 1.400 & $3.024 * *$ \\
\hline Bilai Medium $(\mathrm{BM})$ & 0.83 & & & & & & & & & & -- & $1.976^{*}$ \\
\hline Koser Citrate Medium (KCM) & 0.50 & & & & & & & & & & & -- \\
\hline
\end{tabular}


Table 5 Evaluation of lignocellulosic substrates for cultivation of L. cladopus.

\begin{tabular}{|c|c|c|c|c|c|c|c|c|}
\hline \multirow[b]{2}{*}{ 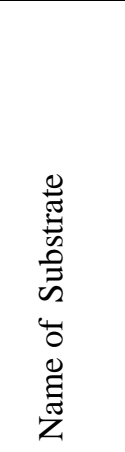 } & \multirow[b]{2}{*}{ 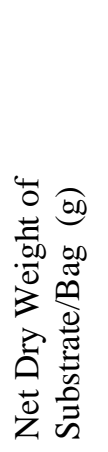 } & \multirow{2}{*}{ 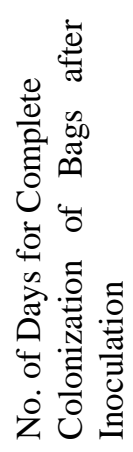 } & \multirow{2}{*}{ 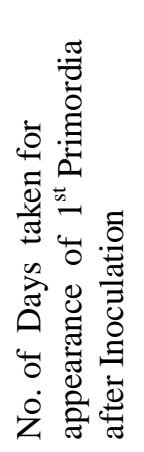 } & \multicolumn{3}{|c|}{$\begin{array}{c}\text { Fresh Weight of } \\
\text { Mushrooms/Bag (g) }\end{array}$} & \multirow{2}{*}{ 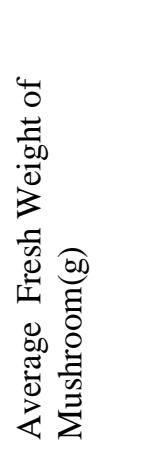 } & \multirow[b]{2}{*}{ 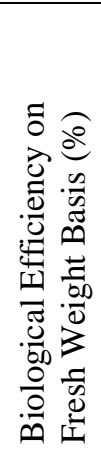 } \\
\hline & & & & Bag 1 & Bag 2 & Bag 3 & & \\
\hline $\begin{array}{l}\text { Wheat } \\
\text { Straw }\end{array}$ & 500 & $7-8$ & 16 & 77.134 & 226.846 & 170.947 & 474.927 & 31.66 \\
\hline $\begin{array}{l}\text { Paddy } \\
\text { Straw }\end{array}$ & 500 & $13-15$ & 19 & 54.240 & 55.998 & 81.191 & 191.429 & 12.76 \\
\hline $\begin{array}{l}\text { Mixture } \\
(1: 1)\end{array}$ & 500 & $9-11$ & 14 & 148.633 & 203.226 & 148.320 & 500.179 & 33.35 \\
\hline
\end{tabular}

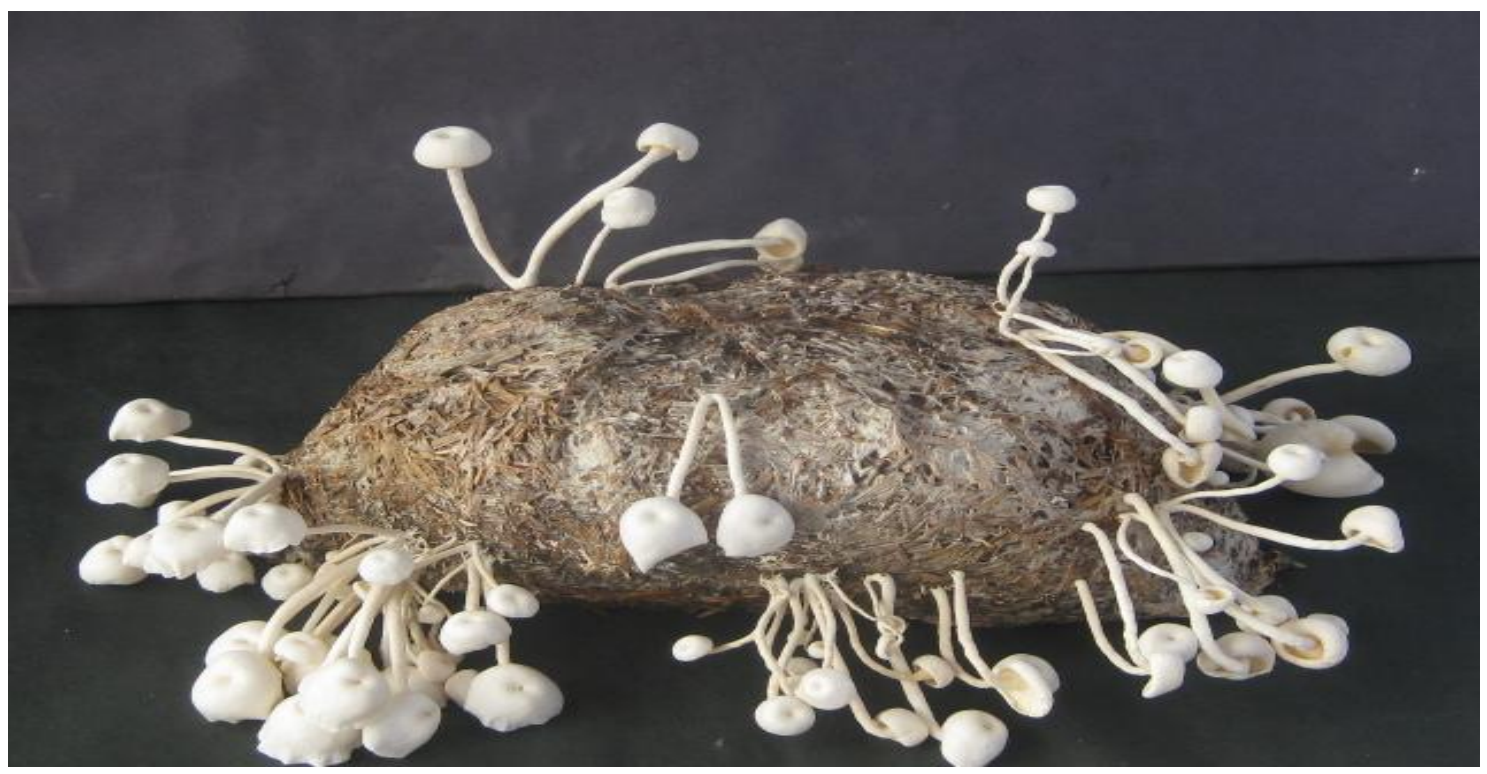

Fig. 3 - Fruiting bodies of L. cladopus on Paddy straw.

incubated substrate bag after few days of complete colonization after which primordia matured into carpophores (Fig. 1, 2, 3). Maximum yield was obtained in 1:1 mixture of wheat and paddy straw followed by wheat straw substrate and paddy straw substrate. Mushroom gave $33.35 \%$ biological efficiency in mixture substrate out of the three substrates followed by $31.66 \%$ biological efficiency

\section{Discussion}

L. cladopus is important both nutritionally and nutraceutically (Gulati et al. 2011). This is a maiden attempt to domesticate this mushroom and understand its media requirements for mass culturing. The results obtained in the present study revealed that the best radial mycelial extension $(4.88 \mathrm{~cm})$ was supported by Malt Extract Medium among all the solid media and best vegetative growth $(8.63 \mathrm{mg})$ on dry weight basis was supported by Malt Broth medium among all the liquid media evaluated. No work of this nature is available on L. cladopus, however for some species including L. connatus Berk., L. squarrosulus Mont. and L. subnudus Berk. there are references 
about evaluation of media and substrates for culturing and cultivation. Singh et al. (1990) evaluated Malt Extract Agar and Sabouraud's Agar as the best solid media for vegetative growth of $L$. connatus and Soyabeen Extract Broth as the best liquid medium for vegetative growth of this mushroom. Gbolagade et al. (2006) evaluated Potato Dextrose Agar and Yellow Corn Agar for vegetative growth of $L$. subnudus. Atri et al. (2007) reported maximum radial growth of $L$. squarrosulus mycelium in Yeast Extract Agar. Amongst the liquid media, Yeast Glucose Medium gave the best vegetative yield of $L$. squarrosulus on dry weight basis and Koser Citrate Medium gave the minimum vegetative yield as given by Atri et al. (2007).

Different workers (Farr 1983, Kuo \& Kuo 1983, Harris 1986, Singer \& Harris 1987) have documented the use of saw dust of various hardwood tree species for the production of shiitake. For successful production of $L$. edodes, Royse (1996) reported a composition of saw dust (80\%), wheat bran $(10 \%)$ and millet (10\%). Oghenkaro et al. (2009) while working with L. squarrosulus showed highest fruiting in Brachystegia nigerica Hoyle \& A. P. D. Jones saw dust supplemented with $1 \% \mathrm{CaCO}_{3}, 1 \%$ sugar and $20 \%$ wheat bran. Upadhyay \& Rai (1999) documented the suitability of wheat straw and paddy straw compost for the cultivation of L. squarrosulus. Fasidi \& Kadiri (1993) reported the stimulation of sporophore emergence by supplementation of agricultural wastes.

The results of the present study are in conformity as is evident from the fact that L. cladopus has been successfully cultivated in the laboratory on lignocellulosic substrates. Malt Extract Agar (MEA) proved as the best solid medium and Malt Broth (MB) as the best liquid medium for the vegetative growth of this species. Healthy wheat grains gave good spawn for cultivation and maximum yield was obtained on the mixture of two substrates (1:1- wheat straw: paddy straw) with biological efficiency of $33.35 \%$.

\section{Acknowledgements}

Thanks are due to Head Department of Botany Punjabi University Patiala for providing laboratory facilities and to D.S.T. and U.G.C. for grant under FIST and DRS (SAP III) Programs, respectively.

\section{References}

Atri NS, Upadhyay RC, Singh R, Saini MK. 2007 - Effect of culture media and physical factors on vegetative growth of Lentinus squarrosulus (Mont.) Singer. Punjab Academy of Sciences 4, $1-2$.

Chang ST, Lau OW, Cho KY. 1998 - The cultivation and nutritive value of Pleurotus sajor-caju. European Journal Applied Microbiology and Biotechnology 1981(12), 58-62.

Chang ST, Miles G. 2004 - Mushroom: cultivation, nutritional value, medicinal effects and environmental impact 2nd edn. CRC Press, Boca Raton, Fla.

FAO. 1990 - Technical guidelines for mushroom growing in the tropics. Food Agricultural Organisation UN, Rome.

Farr DF. 1983 - Mushroom Industry: Diversification with additional species in the United States. Mycologia 75, 351-360.

Fasidi IO, Kadiri M. 1993 - Use of agricultural wastes for the cultivation of L. subnudus in Nigeria. Revista de Biologia Tropical 41, 411-415.

Gbolagade JS, Fasidi IO, Ajayi EJ, Sobowale AA. 2006 - Effect of physicochemical factors and semi-synthetic media on vegetative growth of Lentinus subnudus Berk., an edible mushroom from Nigeria. Food Chemistry 99, 742-747.

Gulati A, Atri NS, Sharma SK, Sharma BM. 2011 - Nutritional Studies on five wild Lentinus species from North-West India. World Journal of Dairy \& Food Sciences 6(2), 140-145.

Harris R. 1986 - Growing Shiitake Commercially. Science Technology Publication Madison, Wisconsin. 
Kadiri M. 1998 - Spawn and fruit body production of Pleurotus sajor-caju in Abeokuta Nigeria. Nigerian Journal of Botany 11, 125-131.

Kuo DD, Kuo MH. 1983 - How to grow forest mushroom (Shiitake). The Mushroom Technology Corp, Naperville, Illinois.

Morais MH, Ramos AC, Matou N, Santous Oliveria EJ. 2000 - Note: production of shiitake mushroom (Lentinus edodes) on lignocellulosic residues. Food Science Technology International 6, 123-128.

Natarajan K, Raaman N. 1981 - Lentinus cladopus - a potential edible mushroom. $3^{\text {rd }}$ International Symposium Plant Pathology, New Delhi.

Oghenekaro AO, Okhuoya JA, Akpaja EO. 2009 - Growth of Lentinus squarrosulus (Mont.) Singer on saw dust of different tropical tree species. African Journal of Food Science 3, 710.

Pegler DN. 1977 - A preliminary Agaric flora of East Africa. Her Majesty's Stationary Office, London.

Pegler DN. 1983 - The genus Lentinus - A World Monograph. Her Majesty's Stationary Office, London.

Purkayastha RP, Chandra A. 1985 - Manual of Indian Edible Mushrooms. Jagmander Book Agency, New Delhi.

Royse DJ. 1996 - Yield stimulation of shiitake by millet supplementation of wood chip substrates. In: Mushroom biology and mushroom products. Penn. State University Press, Philadelphia.

Singer R, Harris B. 1987 - Mushrooms and Truffles. Koeiltz Scientific Books D-6240, Koenig stein/Federal Republic of Germany.

Singh SM, Verma RN, Bilgrami KS. 1990 - Growth dynamics of some lignicolous fleshy fungi of North-Eastern India. Journal of Hill Research 4(1), 24-30.

Thakur K. 1995 - Improvement of edible mushrooms. In: Advances in Horticulture. New Delhi, India.

Tuite J. 1969 - Plant Pathological Methods Fungi and Bacteria. Burges Publishing Company, USA.

Upadhyay RC. 1990 - Cultivation of Oyster Mushroom. Mycology and Plant Pathology Section. NRCM, Chambaghat, Solan.

Upadhyay RC, Rai RD. 1999 - Cultivation and nutritive value of Lentinus squarrosulus. Mushroom Research 8(2), 35-38.

Yadav MC. 2005 - Preparation of pure cultures of Mushrooms. In: Frontiers in Mushroom Biotechnology 13th vol. NRCM, Chambaghat, Solan. 